\title{
Evaluation of Bus Quality Service in Northern Peninsular Malaysia: A Review
}

Shuhairy Norhisham, Nor Najwa Irina Mohd Azlan, Muhammad Fadhlullah Abu Bakar, Wan Ahmad Faiz Wan Mohd Fauzi, Nor Hazwani Nor Khalid

To Link this Article: http://dx.doi.org/10.6007/IJARBSS/v11-i12/11831 DOI:10.6007/IJARBSS/v11-i12/11831

Received: 13 October 2021, Revised: 18 November 2021, Accepted: 30 November 2021

Published Online: 10 December 2021

In-Text Citation: (Norhisham et al., 2021)

To Cite this Article: Norhisham, S., Azlan, N. N. I. M., Bakar, M. F. A., Fauzi, W. A. F. W. M., \& Khalid, N. H. N. (2021). Evaluation of Bus Quality Service in Northern Peninsular Malaysia: A Review. International Journal of Academic Research in Business and Social Sciences, 11(12), 927-935.

Copyright: @ 2021 The Author(s)

Published by Human Resource Management Academic Research Society (www.hrmars.com)

This article is published under the Creative Commons Attribution (CC BY 4.0) license. Anyone may reproduce, distribute, translate and create derivative works of this article (for both commercial and non0-commercial purposes), subject to full attribution to the original publication and authors. The full terms of this license may be seen

at: http://creativecommons.org/licences/by/4.0/legalcode

Vol. 11, No. 12, 2021, Pg. 927 - 935

Full Terms \& Conditions of access and use can be found at http://hrmars.com/index.php/pages/detail/publication-ethics 


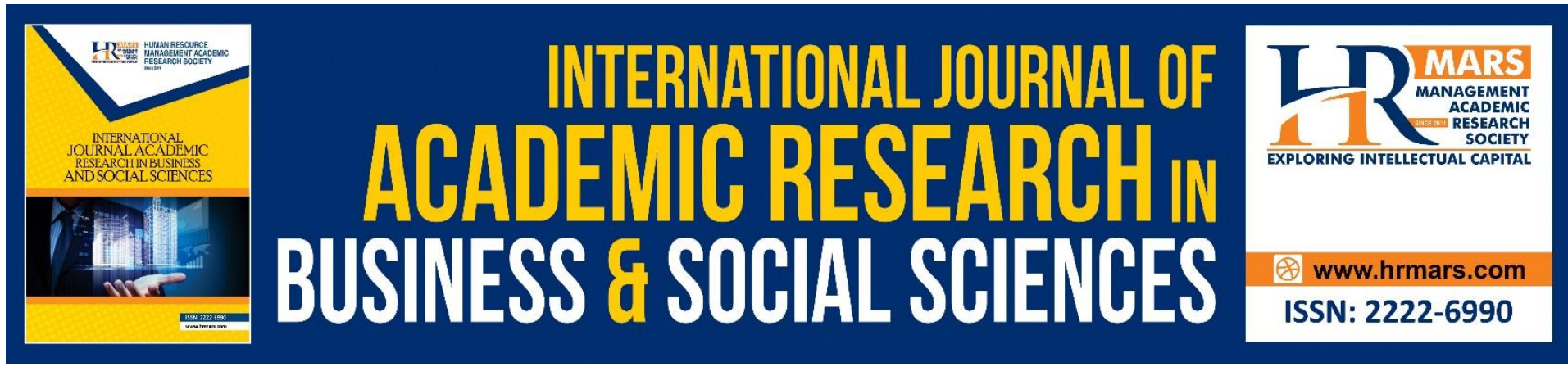

\title{
Evaluation of Bus Quality Service in Northern Peninsular Malaysia: A Review
}

\author{
Shuhairy Norhisham ${ }^{1,2}$, Nor Najwa Irina Mohd Azlan ${ }^{1}$, \\ Muhammad Fadhlullah Abu Bakar ${ }^{1}$, Wan Ahmad Faiz Wan \\ Mohd Fauzi ${ }^{1}$, Nor Hazwani Nor Khalid ${ }^{1,2}$ \\ ${ }^{1}$ Department of Civil Engineering, College of Engineering, Universiti Tenaga Nasional, 43000 \\ Kajang, Selangor, Malaysia, ${ }^{2}$ Institute of Energy Infrastructures (IEI), Universiti Tenaga \\ Nasional, 43000 Kajang, Selangor, Malaysia
}

\begin{abstract}
Public bas is one of the pioneers' public transportations of the country besides train and taxi. However, the quality service of public bus is declining and caused lower anticipation of the riders. The complaints and poor anticipation of bus riders have led to service back out by the bus providers. The current pandemic situation has also made them give up on the continuing the service of public bus. Therefore, the study aimed to review the quality of service of public bus in Northern Peninsular Malaysia. The areas that covered the Northern Peninsular Malaysia are Perlis, Kedah, Penang, and Perak. The attributes on the quality of service for bus focused are on-time performance, passenger load factor, and service frequency. Those attributes are reviewed and compared with past studies. The result of the study found that the all the attributes are influential in maintaining the quality of service of the bus at Northern Peninsular Malaysia. Authorities and bus providers at Northern Peninsular Malaysia need to put a high attention on giving the best quality of service prior to the attributes for the bus riders to enjoy the public bus transportation
\end{abstract}

Keywords: Public Bus, Quality of Service, Northern Peninsular Malaysia, On-Time Performance, Passenger Load Factor, Service Frequency.

\section{Introduction}

Nowadays, an urbanization occurs widely and rapidly across the world. The most significant factor in European civilization is urbanization as the people living in European countries already reached approximately 80\% (Antrop, 2000; Borhan et al., 2019). In 2019, United Nations estimated that 4.2 billion people which is half of the world's population live in urban area and the numbers will keep rising up to 6 billion people by 2041 (Kuddus et al., 2020). The increased in the urbanization has resulted to high demand of public transportation. Several types of public transportations include buses, trains, ferries, and shared taxis provide mobility to citizens especially around the city areas (Litman, 2021).

One of the most economical choice of public transportation is bus because of the readily available roads from one place to another. According to the Department of Transport, the bus schemes provide worth more than their cost (Alston et al., 2021). Buses is one of the 
cheapest and fastest way to improve transportation and environmental pollution. A full capacity of double decker bus can take off 75 cars on the road and eventually reduce traffic congestion and tail-pipe emissions (Fuller, 2019).

The usage of public bus by citizens is reducing every day due to rising complaints of the bus quality of service (Noh, 2015). There are several factors that disrupt the quality of service for bus, namely limited facilities, low coverage of interchanges, inconvenience fleets, limited dispatch of passengers trips, and long waiting time (Bachok et al., 2014; Rahim et al., 2021). All the rising issues on quality of service for public bus have caused the bus services in Malaysia to paralyze especially in Northern region. Kaos (2012) discovered that the bus service of Lean Hock Sdn Bhd in Pulau Pinang and Kedah have completely shut down after 64 years of operation. Also, Bernama (2018) reported that Cityliner discontinued their six out of seven public bus routes in Kedah because their company unable to keep up with the cost of operation.

Although the quality service of public bus is questioned by the citizens, public bus is the most preferable mode of transportation because of its wide coverage of destination points (Rahim et al., 2021). A research by Sufahani et al. (2016) found that public bus in is chosen over airline by most tourists and local citizens in Kelantan due to its price wise, accessibility and convenience. To ensure continues public bus service to citizens and tourists, quality of service for public bus need to be improved thoroughly. This study aims to review the quality service of bus in Northern region, Malaysia. The attributes considered in the quality of service for bus are on-time performance, service frequency, and passenger load factor. Besides that, each attribute on quality of service for bus will be compared based on the past studies.

\section{Study Area}

The quality of service for public bus is reviewed focusing areas of Northern Peninsular Malaysia. Primarily, only the area of few states is considered which include Perlis, Kedah, Penang, and Perak. For Perlis, the main public bus provider is myBAS Perlis under Land Public Commission (SPAD). There are many bus providers available in Kedah namely, Kenderaan Langkasuka Sdn. Bhd., HBR Group Sdn. Bhd., and The Jalan Langgar Transport Company Sdn. Bhd. Some part of Northern region in Kedah is covered by myBas Kangar.

In addition, there are a lot of bus service provider in Penang. The most established bus provider is Rapid Penang under government-owned company (Prasarana Malaysia) and starts operating in year 2007. Rapid Penang covers almost all places in Penang and has its own branch public bus service, CAT Free Bus and Penang Hop-On Hop-Off. Another study area is Perak which used myBas Ipoh as their major public bus service. Similar to Perlis, myBas Ipoh a stage bus business incorporated with SPAD.

\section{Quality of Service for Public Bus}

The quality service of public bus is evaluated based on the performance of every bus provided by respective operator (Bakar et al., 2021; Eboli et al., 2018). Public bus provider that has high quality of service will meet customer's needs and satisfactions. When a public bus provider can ensure high quality of service, more customers are attracted to use public bus as their mode of transportation for daily life and travel purpose (Islam et al., 2014). Moreover, the bus companies can build a long-term profitable organisation with a good quality of service and high customer satisfaction (Laisak et al., 2021). 
Quality of service is very subjective as it involved intangible feelings by customer's individual preferences. The quality of service can be either positive or negative as it depends on word of mouth and experiences from the customers. Different subject of study has different quality of service attributes. For instance, Famiyeh et al (2018) considered social attributes in quality of service in banking sector, while Abbasi-Moghaddam et al (2019) used straightforward attributes in healthcare sector. In this study, on-time performance, service frequency, service hours, and passenger load factors are the service quality attributes explored for public bus transportation.

\section{On-Time Performance}

A previous study by Berrebi et al (2015) revealed that the bus passengers preferred shorter waiting times so that they do not feel anxious while waiting at the bus stop. There are a few studies covered the study area of Northern Peninsular Malaysia. In Perlis, a study regarding on-time performance provided by myBas Perlis is investigated. The on-time percentage for myBas Perlis routes is $63.33 \%$ and $56.67 \%$ early than the published schedule for weekends and weekdays respectively (Zahir \& Haron, 2019). The quality of service based on the on-time performance for myBas Perlis is A for the headway on the selected route. Norhisham et al. (2021) determined the on-time performance for bus service at Alor Setar, Kedah. The study found that the most routes at Alor Setar achieved service quality of E where almost $70 \%$ of the buses departed later than the scheduled time.

Three out five bus routes in Georgetown, Penang found exceeded the longest waiting time (30 minutes) and the service quality fall at $D$ and $E$ (Fadhlina et al., 2021). For bus services from Ipoh to Lumut (Perak), the results found that the on-time performance and service regularity are low which affect the bus riders expectations (Suwardo et al., 2009). Therefore, the on-time performance for bus service vary according to the study area. From the past studies reviewed, only Perlis provide good on-time performance for their bus service compared to other study areas of Perlis, Penang, and Perak.

In addition, on-time performance for public bus service also being explored by other researchers around the world. The previous studies regarding on-time performance for public bus service are established in Table 1.

Table 1. On-time performance for public bus service from previous studies

\begin{tabular}{|l|l|l|}
\hline Author & \multicolumn{1}{|c|}{ City } & \multicolumn{1}{c|}{ Explanation } \\
\hline Halls (2020) & $\begin{array}{l}\text { Los Angeles County, } \\
\text { USA }\end{array}$ & $\begin{array}{l}\text { - Focused on arrival time } \\
\text { - Based on LA Metro guidelines. }\end{array}$ \\
\hline $\begin{array}{l}\text { Palm et al. } \\
(2020)\end{array}$ & Toronto, Canada & $\begin{array}{l}\text { - Based on TCQSM 3rd Edition. } \\
\text { - Computing in mean, median, minimum, and } \\
\text { maximum percentage of on-time } \\
\text { performance. }\end{array}$ \\
\hline $\begin{array}{l}\text { Norhisham et } \\
\text { al. (2018) }\end{array}$ & $\begin{array}{l}\text { West Klang Valley, } \\
\text { Malaysia }\end{array}$ & $\begin{array}{l}\text { - Based on TCQSM 3 }{ }^{\text {rd }} \text { Edition. } \\
\text { - Adding categorization from QOS A to QOS E. }\end{array}$ \\
\hline
\end{tabular}

\section{Service Frequency}

The service frequency for bus service at Northern Peninsular Malaysia is investigated. The headway and number of vehicles per hour closely related to service frequency. The headway time for bus service in Perlis found to be within 45 to 50 minutes which is the service quality on service frequency graded at $\mathrm{E}$ (Zahir \& Haron, 2019). The acceptable headway time should 
be in between 5 to 30 minutes from the planned time to get good service frequency for bus service. The service frequency in Alor Setar, Kedah is classified as an F for service quality means it is below the customer's satisfaction (Norhisham et al., 2021). The frequency of bus service is based on average departure time intervals between bus trips provided by bus operator.

Bus service in Penang under Rapid Penang has the highest service frequency of five to ten minutes. Also, the lowest service frequency for bus service in Penang is up to 50 minutes for bus arrival or departure (Haron et al., 2016). The current bus operator in Perak provides bus service as frequent as one and two buses per hour during off-peak and peak hours respectively. From the number of service frequency, the bus service quality at Perak is categorized as D and E for peak and off-peak hours respectively (Napiah et al., 2011). Other previous studies involving other cities are established in Table 2.

Table 2. Service frequency for public bus service from previous studies

\begin{tabular}{|l|l|l|}
\hline Author & \multicolumn{1}{|c|}{ City } & \multicolumn{1}{c|}{ Explanation } \\
\hline $\begin{array}{l}\text { Gkiotsalitis } \\
(2021)\end{array}$ & Asia Pacific & $\begin{array}{r}\text { - The circular bus in Asia Pacific is one high } \\
\text { service frequency with } 245 \text { daily trips. } \\
\text { - High frequency of bus service closely } \\
\text { related with the bus waiting time. }\end{array}$ \\
\hline $\begin{array}{l}\text { Yantao et al. } \\
(2021)\end{array}$ & USA & $\begin{array}{r}\text { - Less service frequency increased vehicle } \\
\text { occupancy and increase riders waiting time. } \\
\text { - Signals influence the service frequency by } \\
\text { lowering vehicle's average speed. }\end{array}$ \\
\hline Liu et al. (2021) & China & $\begin{array}{l}\text { - The service frequency impacted the level of } \\
\text { service for public bus transportation. }\end{array}$ \\
\hline
\end{tabular}

\section{Passenger Load Factor}

Passenger load factor is relative to the comfort and convenience of transportation facilities. The load factor is evaluated by number of passengers seated in the bus over the number of seats available in the bus. The Kangar Transportation Hub in Perlis received approximately 400 bus passengers at one time (Azmi et al., 2020). So, the passenger load factor will also be high parallel to the number of passengers received at the hub. The passenger load factor for public bus in Northern Peninsular Malaysia is explored. Norhisham et al. (2021) discovered that the average passenger load factor in Alor Setar, Kedah is found at 0.22 which classified as $A$ for service quality.

Zainol (2017) measured bus service at Georgetown, Penang as a Central Area Transit. Outcome of the study found that the congestion and high passenger load reduced the bus service's reliability and efficiencies. the In Perak specifically their capital city of Ipoh, the load factor percentage for bus service during weekend was at $67 \%$ higher than weekdays at $51 \%$. Table 3 shows the past studies on passenger load factor for public bus service for different countries. 
Table 3. Passenger load factor for public bus service from previous studies

\begin{tabular}{|l|l|l|}
\hline Author & City & Explanation \\
\hline $\begin{array}{l}\text { Hellekes \& } \\
\text { Winkler (2021) }\end{array}$ & Germany & $\begin{array}{r}\text { Increasing demand of public transport } \\
\text { system required changing in the load factors. }\end{array}$ \\
\hline $\begin{array}{l}\text { Juanita et al. } \\
\text { (2021) }\end{array}$ & $\begin{array}{l}\text { Central Java, } \\
\text { Indonesia } \\
\text { Shen et al. } \\
(2016)\end{array}$ & $\begin{array}{r}\text { During pre-pandemics, the passenger load } \\
\text { factor is at high level. } \\
\text { The pandemic resulted in drastic drop of } \\
\text { load factor which is also an economic } \\
\text { indicator. }\end{array}$ \\
\hline & Harbin City, China & $\begin{array}{l}\text { - Passenger load factor affect passenger } \\
\text { comfort perception. } \\
\text { Comfort level for standing passenger lower } \\
\text { than seated passenger. }\end{array}$ \\
\hline
\end{tabular}

\section{Conclusion}

In this paper, it can be concluded that there are many factors affecting the quality of service for public bus transportation. Three of the attributes (on-time performance, service frequency, and passenger load factor) are discussed and reviewed thoroughly. Each of the attributes gives an effect to the bus service differently. By maintaining the on-time performance, service frequency, and passenger load factor at an A for quality of service eventually improve the image of public bus transportations in Northern Peninsular Malaysia. In addition, it can be noted by the bus service providers to provide the bus services with the highest quality for each attribute. The country and bus service provider will get benefits economically from it as the number of bus users also will increase parallel to the highest quality of bus service provided.

\section{Acknowledgement}

The authors acknowledge the Institute Energy, Universiti Tenaga Nasional for providing great facilities and Yayasan Canselor Universiti Tenaga Nasional for funding this study (202101015YCU).

\section{Corresponding Author}

Dr. Shuhairy Norhisham

Senior Lecturer at Universiti Tenaga Nasional, Malaysia.

Email: shuhairy@uniten.edu.my

\section{References}

Abbasi-Moghaddam, M. A., Zarei, E., Bagherzadeh, R., Dargahi, H., \& Farrokhi, P. (2019). Evaluation of service quality from patients' viewpoint. BMC Health Services Research, 19(1), 1-7. https://doi.org/10.1186/s12913-019-3998-0

Alston, P., Khawaja, B., \& Riddell, R. (2021). Public Transport, Private Profit: The Human Cost of Privatizing Buses in the United Kingdom.

Antrop, M. (2000). Changing patterns in the urbanized countryside of Western Europe. Landscape Ecology, 15(3), 257-270. https://doi.org/10.1023/A:1008151109252

Azmi, M., Seman, N. F. A., \& Taib, M. Y. M. (2020). Amenities performance on transportation hub: A case study of medium-sized non-centered state. Journal of Critical Reviews, 7(8), 1-5. https://doi.org/10.31838/jcr.07.08.01 
Bachok, S., Osman, M. M., \& Ponrahono, Z. (2014). Passenger's Aspiration Towards Sustainable Public Transportation System: Kerian District, Perak, Malaysia. Procedia Social and Behavioral Sciences, 153, 553-565. https://doi.org/10.1016/j.sbspro.2014.10.088

Bakar, M. F. A., Norhisham, S., Fai, C. M., \& Baharin, N. L. (2021). Comparison of Service Quality and Stakeholder Perception on Bus Services for Urban Transportation in Klang Valley. International Journal of Academic Research in Business and Social Sciences, 11(2), 1352-1362. https://doi.org/10.6007/ijarbss/v11-i2/9210

Bernama. (2018). Cityliner halts six out of seven routes in north. TheSundaily. https://www.thesundaily.my/archive/cityliner-halts-six-out-seven-routes-northBUARCH564706

Berrebi, S. J., Watkins, K. E., \& Laval, J. A. (2015). A real-time bus dispatching policy to minimize passenger wait on a high frequency route. Transportation Research Part B: Methodological, 81, 377-389. https://doi.org/10.1016/J.TRB.2015.05.012

Borhan, M. N., Hakimi Ibrahim, A. N., Syamsunur, D., \& Rahmat, R. A. (2019). Why public bus is a less attractive mode of transport: A case study of Putrajaya, Malaysia. Periodica Polytechnica Transportation Engineering, 47(1), 82-90.

https://doi.org/10.3311/PPtr.9228

Eboli, L., Forciniti, C., \& Mazzulla, G. (2018). Spatial variation of the perceived transit service quality at rail stations. Transportation Research Part A: Policy and Practice, 114(February), 67-83. https://doi.org/10.1016/j.tra.2018.01.032

Fadhlina, S., Fisal, M., Sabahiah, N., \& Sukor, A. (2021). Level of Service ( LOS ) and Bus Headways : A Case Study of George Town, Penang. Jurnal Kejuruteraan, 33(3), 623-632.

Famiyeh, S., Asante-Darko, D., \& Kwarteng, A. (2018). Service quality, customer satisfaction, and loyalty in the banking sector: the moderating role of organizational culture. International Journal of Quality and Reliability Management, 35(8), 1546-1567.

Fuller, R. (2019). The Cross-Sector Benefits of Backing The Bus.

Gkiotsalitis, K. (2021). Improving service regularity for high-frequency bus services with rescheduling and bus holding. Journal of Traffic and Transportation Engineering (English Edition). https://doi.org/10.1016/j.jtte.2020.06.002

Halls, C. (2020). The Effect of Bus lane Management Techniques on Operator Experience, Safety, and On-Time Performance. https://escholarship.org/uc/item/1h710137

Haron, S., Mansor, S., \& Hisam, W. S. M. N. (2016). Quality approach on strengthening Rapid Penang services in Penang tourism sites. AIP Conference Proceedings, 1774. https://doi.org/10.1063/1.4965077

Hellekes, J., \& Winkler, C. (2021). Incorporating passenger load in public transport systems and its implementation in nationwide models. Procedia Computer Science, 184, 115122. https://doi.org/10.1016/j.procs.2021.03.022

Islam, R., Chowdhury, M. S., Sarker, M. S., \& Ahmed, S. (2014). Measuring Customer's Satisfaction on Bus Transportation. American Journal of Economics and Business Administration, 6(1), 34-41. https://doi.org/10.3844/ajebasp.2014.34.41

Juanita, J., Setiawan, T. H., \& Ma'ruf, A. (2021). The Operational Performance of Mass Transportation Before Covid-19 and New Normal Life: Case Study BRT TransJateng, Central Java. Advances in Science, Technology and Engineering Systems Journal, 6(3), 361-366. https://doi.org/10.25046/aj060342

Kaos, J. J. (2012). Penamatan Perkhidmatan Bas Henti-Henti Jejas Ribuan Penumpang Semasa / mStar. MStar. 
https://www.mstar.com.my/lokal/semasa/2012/01/03/penamatan-perkhidmatan-bashenti-henti-jejas-ribuan-penumpang

Kuddus, M. A., Tynan, E., \& McBryde, E. (2020). Urbanization: A problem for the rich and the poor? Public Health Reviews, 41(1), 1-4. https://doi.org/10.1186/s40985-019-0116-0

Laisak, A. H., Rosli, A., \& Sa'adi, N. (2021). The Effect of Service Quality on Customers' Satisfaction of Inter-District Public Bus Companies in the Central Region of Sarawak, Malaysia. International Journal of Marketing Studies, 13(2), 53.

https://doi.org/10.5539/ijms.v13n2p53

Litman, T. (2021). Evaluating Public Transit Benefits and Costs - Best Practices Guidebook. Victotia Transport Policy Institute, 1-138.www.vtpi.orgInfo@vtpi.org

Liu, J., Zhao, H., Li, J., \& Yue, X. (2021). Operational strategy of customized bus considering customers' variety seeking behavior and service level. International Journal of Production Economics, 231(January).

Napiah, M., Kamaruddin, I., \& Suwardo. (2011). Punctuality index and expected average waiting time of stage buses in mixed traffic. WIT Transactions on the Built Environment, 116, 215-226. https://doi.org/10.2495/UT110191

Noh, N. A. M. (2015). Factors Influencing Bus Service Quality - Perspectives of User.

Norhisham, S., Bakar, M. F. A., Syamsir, A., Zaini, N., Baharin, N. L., Shkuri, N. S. M., \& Saad, N. M. (2021). Evaluating the quality of services for bus performance in Alor Setars. IOP Conference Series: Earth and Environmental Science, 708(1).

https://doi.org/10.1088/1755-1315/708/1/012038

Norhisham, Shuhairy, Katman, H. Y., Ismail, N., Abd Halim, S. N. N., Ismail, A., \& Borhan, M. N. (2018). Evaluation on time performance for public bus service in West klang valley. International Journal of Engineering Research and Technology, 11(3), 403-415.

Palm, M., Shalaby, A., \& Farber, S. (2020). Social Equity and Bus On-Time Performance in Canada's Largest City. Transportation Research Record, 2674(11), 329-342. https://doi.org/10.1177/0361198120944923

Rahim, M. N. A., Aziz, Z. A., Hassan, A. A. M., Yazid, M. F. A., Razik, M. A., Miskam, Z., \& Mustapha, N. (2021). Factors Influencing Passengers' Preference towards Public Bus Transportation from Kelantan to Northern Region. Turkish Journal of Computer and Mathematics Education (TURCOMAT), 12(3), 2572-2583.

https://doi.org/10.17762/turcomat.v12i3.1257

Shen, X., Feng, S., Li, Z., \& Hu Background, B. (2016). Analysis of bus passenger comfort perception based on passenger load factor and in-vehicle time. SpringerPlus. https://doi.org/10.1186/s40064-016-1694-7

Sufahani, S., Muhammad, M., \& Ismail, Z. (2016). The Statistical Analysis of the Tourist's Summary Profile and Behavior in Kelantan, Malaysia. International Journal for Research \& Development in Technology, 6(3), 54-58.

Suwardo, Napiah, M. B., \& Kamaruddin, I. B. (2009). On-Time Performance and Service Regularity of Stage Buses in Mixed Traffic. International Journal of Business, Economics, Finance and Management Sciences, 1(3), 1137-1144.

Yantao, H., Kockelman, K. M., \& Truong, L. T. (2021). SAV Operations on a Bus Line Corridor: Travel Demand, Service Frequency, and Vehicle Size. Journal of Advanced Transportation. https://doi.org/10.1155/2021/5577500

Zahir, M. H., \& Haron, S. (2019). The study of headway patterns and level of service in myBAS ridership. Journal of Physics: Conference Series, 1349(1). https://doi.org/10.1088/17426596/1349/1/012082 
Zainol, R. (2017). Auditing a Central Area Transit (Cat) bus service in a Malaysia's world heritage site: A case study of Georgetown, Penang. Auditing a Central Area Transit (Cat) Bus Service in a Malaysia's World Heritage Site: A Case Study of Georgetown, Penang, 12(5), 61-73. 